\title{
The Impact of Economic Specialization on Regional Economic Development in the European Union: Insights for Formation of Smart Specialization Strategy
}

\author{
Giedrè Dzemydaitè (iD
}

check for

updates

Citation: Dzemydaitè, Giedrè. 2021. The Impact of Economic

Specialization on Regional Economic Development in the European Union Insights for Formation of Smart Specialization Strategy. Economies 9: 76. https://doi.org/10.3390/ economies 9020076

Academic Editors: Luís Carvalho and Joana Costa

Received: 23 March 2021

Accepted: 11 May 2021

Published: 13 May 2021

Publisher's Note: MDPI stays neutral with regard to jurisdictional claims in published maps and institutional affiliations.

Copyright: (C) 2021 by the author. Licensee MDPI, Basel, Switzerland. This article is an open access article distributed under the terms and conditions of the Creative Commons Attribution (CC BY) license (https:/ / creativecommons.org/licenses/by/ $4.0 /)$.
Faculty of Economics and Business Administration, Vilnius University, Saulètekio av. 9, LT-10222 Vilnius, Lithuania; giedre.dzemydaite@evaf.vu.lt

\begin{abstract}
The smart specialization concept was implemented in the EU in 2014, stating that regions have to specify specialization areas for development of innovations. Economic specialization reveals a comparative advantage in that field. However, there are different arguments linking specialization to economic development. This study analyzes these arguments and aims to investigate the impact of economic specialization on regional economic development and to give insights into identifying prospective areas in regional economies. A panel fixed effect estimation of industry-level regional data suggests that economic specialization in broader regional employment, called relative specialization, is ambiguously associated with economic development. Our findings suggest that neither economic specialization nor economic diversity are a clear-cut solution for ensuring economic growth. Economic structure in EU regions differs, and there is no one answer for which approach is better for economic development. Specialization measures, particularly the location quotient, cannot fully capture the dynamics in the industry structure that could be essential for formation of regional development strategy.
\end{abstract}

Keywords: economic structure; economic specialization; smart specialization; economic growth; EU regions; tradable sectors

\section{Introduction}

European regional development policy has been counted for more than two decades. As stated in the Treaty of Rome, the general focus of this policy is to reduce regional differences throughout the common European market. About one-third of the EU budget was dedicated to reducing regional disparities for programming periods of 2007-2013 and 2014-2020. Due to emerging challenges and global competition, European Cohesion Policy was reformed in 2014, strengthening the innovation-led industrial policy perspective (McCann and Ortega-Argilés 2013; Benner 2020). The specific features of the EU context significantly influenced the logic of the changes.

Industrial change focusing on innovation is one of the critical challenges of the 21st century that refers to ongoing economic and social development in all industries and fields of activity-both emerging and traditional sectors in decline. At the European level, the vast majority of socio-economic players agreed on the need for a proactive approach to industrial change from two perspectives: fostering higher value-added activities in regions and dealing with social consequences due to changes in the economy and the European labor market. Such a proactive approach to industrial change was introduced in the EU in 2014. The European Commission stated prerequisite requirements for the EU regions to receive funding from the European Regional Development Fund. Regions had to choose their specific specialization areas for innovation and to adopt research and innovation strategies for smart specialization.

Smart specialization strategy reveals a place-based policy approach to regional economic development (Barca et al. 2012). Regions identified strategic areas for intervention 
based on the analysis of the economy's strengths and the potential of regional innovation systems (European Commission 2015, 2017a, 2017b; McCann and Ortega-Argilés 2015). Place-based policies are supposed to stimulate private sector investment and economic growth in the treated place, and as such, they are sometimes difficult to appraise and evaluate (Duranton and Venables 2018).

This approach to regional innovation policy spreads worldwide. Other countries and regions outside the EU (in Latin America, sub-Saharan Africa, Eastern partnership countries, and others) investigate opportunities to apply regional research and innovation strategies for smart specialization (Dosso et al. 2020; Barroeta et al. 2017; Kleibrink et al. 2017). At the core of policy formation comes the selection of smart specialization areas and raises a question of the role of economic specialization in this process.

The main question behind the policymaking is how to shift regional economic development into more smart growth and how to facilitate new prospective industries and activities to flourish. The idea behind this is that regions have to use their strengths and develop sectors and activities where regional actors had a related experience. This leads to a diversification process in relation to a current specialization (Foray et al. 2009, 2011; Balland et al. 2019). Diversification means that new prospective activities are emerging. Specialization means that these activities relate to the regional context and previous practice. Therefore, in the first step of policy formation comes an analysis of regional economic structure and current specialization and innovation areas.

One of the available methods is an analysis of regional economic specialization (Foray et al. 2012). It is a quantitative analysis to calculate degrees of specialization of regional economies based on employment or value-added data. Specialization indexes, usually the location quotient (LQ) index, indicate critical masses of activity. Even though it does not reveal innovation-driven linkages, it still gives evidence of a regional economy where value added and exports are generated in the economy and where knowledge and competencies are concentrated (Foray 2015). Various EU regions applied the LQ index for specialization analysis as the first step of formation of a smart specialization strategy. Then, through the entrepreneurial discovery process, regional actors further discussed prospective future economic growth areas and formulated smart specialization strategies.

Even though a measurement of economic specialization in the sense of LQ indexes are broadly involved in a policy formation around the EU and other countries (Foray et al. 2012; Postoiu and Dachin 2014), there is still a gap in the scientific literature for giving more evidence and critical analysis of the applicability of quantitative measures for policy formation. A recent discussion of Hassink and Gong (2019), Foray (2019), and Benner (2020) underlined a need for rigorous measurements of prospective areas and a critical judgment of the currently applied techniques in policy formation.

Prioritization of prospective areas proved difficult and limited capacities of implementing agencies, especially in lagging regions (e.g., Capello and Kroll 2016; Karo et al. 2017; Gianelle et al. 2019; Trippl et al. 2020). Proper quantitative or qualitative techniques could reduce the risk of local actors' incapacity. Most recently, Balland et al. (2019) suggested involving a new measurement of relatedness in policy formation that is expanding knowledge in this field. Kemeny and Storper (2014) critically analyzed absolute and related specialization for the USA regions and suggested that relative specialization cannot capture dynamics in the economic structure. For this reason, a critical assessment of quantitative techniques is a question for further scientific research that is not sufficiently covered for the EU regions.

In this paper, we followed these thoughts and aimed to investigate the impact of economic specialization on regional economic development and give insights about identifying prospective areas in regional economies. The research question was to what extent higher specialization rates, measured by location quotient, reveal prospective areas for economic growth and to what extent such analysis could be valuable in the policy formation of smart specialization strategies. The novelty of the paper is that we match an impact evaluation with insights for formation of smart specialization strategies. Most 
studies present the economic nature of how regions evolve rather than give insights into the application of economic specialization measures in the process of policy formation, apart from some research, e.g., Kemeny and Storper (2014), who analyzed USA regional data, or Balland et al. (2019), who suggested a new framework. This paper gives insights into how to divide tradable and non-tradable sectors essential for economic specialization analysis. It supplements previous explanations (Jensen and Kletzer 2005; Moretti and Thulin 2012; Kemeny and Storper 2014). A dataset covers the most recent data of the EU regions that gives a sense of a broader EU perspective rather than a case study of a region or country, but still with economic activities distributed in comparatively disaggregated levels (48 sectors). Case studies could be found from a variety of researchers, i.e., Postoiu and Dachin (2014), Paliokaite et al. (2015), and Sotarauta and Suvinen (2019).

The paper consists of four main parts. Section 2 systemizes related literature and gives a general image of the impact of an economic specialization on regional economic development. It reveals the gains and drawbacks of an economic specialization to a regional economy. Section 3 explains research methods and data. This section also presents an approach to the division between tradable and non-tradable sectors that supports a selection of economic sectors involved in the analysis. Section 4 reveals the estimation results of the panel data model. Sections 5 and 6 summarize the main findings and explain policy implications.

\section{Related Literature}

There are two sides of the coin while analyzing the economic specialization and its impact on economic development. Both specialization and diversification processes of economic structure could benefit the regional economy from different perspectives. From the most recent literature overview, new innovative activities are supposed to emerge as a diversification process in current specialization areas (Foray et al. 2011; Hassink and Gong 2019). Regions need to continuously reinvent themselves by developing new activities that mean a process of diversification (Balland et al. 2019).

The explanation of specialization and diversification processes and their impact on economic development comes from the works of Jacobs (1969), Marshall (1920), Arrow (1962), and Romer (1990), who analyzed agglomeration effects and high spatial concentration of companies in the same or different sectors. These evolved into dominant theoretical concepts, most recently analyzed by Boschma and Martin (2010), Content et al. (2019), and other researchers.

Because of the limited size of a local market, economic specialization of a region forms when firms sell goods or services in foreign markets (Kemeny and Storper 2014). Higher economic specialization rates relate to higher exports and reflect a comparative advantage of companies in that field. Change of production level in exporting sectors influences regional income directly and indirectly through income-multiplying effects (Moretti and Thulin 2012; Capello 2016, p. 122). The output of tradable sectors is not limited by local income and market size. If an external demand is growing and the region's output enjoys increasing rations of its unit price relative to imports, it benefits the economy's overall income. The tradable sectors considerably impact overall productivity in the European Union (Friesenbichler and Glocker 2019).

Increasing the size of localized activity, which means a process of economic specialization, could also enhance the productivity of firms through sharing of input suppliers, a specialized labor market and its development, and technological learning and spillover effects through actors spread across different organizations (Duranton and Puga 2004; Henderson 2003). Industrial concentration and economic specialization lead to positive externalities in the local economy that could affect economic development, employment, and income (De Groot et al. 2009).

On the other hand, arguments are linking a more diversified economic structure to regional economic development. The greater diversity in the economy could generate the greater capacity to create more types of goods and services (Jacobs 1969). The spatial prox- 
imity of companies from different sectors could create positive externalities to economic development. It contributes to the exchange and combination of ideas between different sectors, which is beneficial for creating new activities. Even though knowledge is spread primarily within the individual economic sector, it could also spread across sectors. If the variety of companies and skills are related, it is supposed to give more opportunities for regional economic development (Mameli et al. 2012; Van Oort et al. 2015; Misiak and Dykas 2021). Regions are more likely to diversify into complex technologies when relatedness is high (Balland et al. 2019).

An additional shortcoming of the specialization of regions is the risk of changing technologies or black swans. When a particular economic sector is affected by an unfavorable business cycle, a highly specialized territory may experience a severe economic downturn (Dietz and Garcia 2002; Sidlauskaitè-Riazanova and Miškinis 2019). One example is the COVID-19 crisis that revealed an uncompromising slump of regions specialized in tourism (Šidlauskaitè-Riazanova 2020; Skare et al. 2021; Zhang et al. 2021). Highly specialized regions could become a hostage of their economic structure. The question is to what extent such regions can diversify in new economic activities in general and in the case of a crisis. Different goods and activities are associated with differed technological and learning opportunities. Regions specialized in dynamic and innovative industries are better positioned to achieve sustained economic growth than others (Hausmann et al. 2007). Diversification into more complex technologies is attractive but challenging for European Union regions to accomplish (Balland et al. 2019). A critical mass of capabilities to develop collective learning and compete at a global level is needed (Iacobucci and Enrico 2016). There is a risk of a lack of local preconditions for innovation development in regions with few research institutions and high-tech clusters. These conditions form challenges for developing new specializations in more complex activities where regions do not have an existing practice.

According to Capello and Kroll (2016), there are issues in developing high valueadded specializations in peripheral regions. If the regional economy is highly dependent on multinational enterprises (MNEs) that are settled in the region, a repositioning of regions in international value chains can often not be controlled by policymakers from within these regions alone. MNEs have their global corporate strategies and could not be specifically interested in becoming engaged with these regional local development strategies. MNEs remain vulnerable to more general corporate plans. Decisions to reallocate activities are out of the control of the regional government.

Even though different arguments link more specialized or diversified economic structure to economic development, a variety of arguments comes for economic specialization through the lenses of comparative advantage, intra-sectoral dissemination and knowledge spillover within the sector, and localization externalities that come from the economic specialization. The extent to which economic specialization influences regional economic development remains a question for scientific debate.

\section{Research Methodology}

\subsection{Model Specification}

In this paper, we investigated the relationship between economic specialization and regional economic growth in European regions. The research framework is built on a neoclassical growth theory (Solow 1952) that is commonly applied for modeling economic growth in various research (Liu 2019). Control variables in a model represent changes in capital and labor expressed by indicators of gross fixed capital formation, persons with tertiary education, or working-age population. These variables are common in an economic growth analysis (Akcigit 2017). For this study, we involved a measure of economic specialization in the model as an independent variable.

There are different approaches on how to measure economic specialization. Most studies measure the level of relative specialization by location quotients following Glaeser et al.'s (1992) idea. This measure is applied in the policymaking process to evaluate prospective smart specialization areas (Foray et al. 2012). For this reason, we used a 
relative specialization indicator based on location quotient calculations. A coefficient of locations quotients $\left(L Q_{r i}\right)$ incorporates the effect of regional industrial scale by the following expression (Lu et al. 2011):

$$
L Q_{r i}=\frac{E_{r i} /\left(\sum_{i=1}^{N} E_{r i}\right)}{\left(\sum_{r=1}^{M} E_{r i}\right) /\left(\sum_{i=1}^{N} \sum_{r=1}^{M} E_{r i}\right)}=\frac{S_{r i}}{S_{i}}
$$

where $L Q_{r i}$ - the location quotient of industry $i$ in region $r, r=1, \ldots, M, i=1, \ldots, N$; $E$-the number of employees (employment); $S_{r i}$ - the employment share of industry $i$ in region $r ; S_{i}$-the employment share of industry $i$ in total employment.

The relative specialization of region $r$ was measured by the average location quotient weighted by the number of people employed:

$$
\text { Specialization }_{r}=\sum_{i}^{N} \frac{E_{r i}}{E_{r}} L Q_{r i}
$$

where $E_{r i}$ denotes the number of employees in region $r$ in industry $i, r=1, \ldots, M, i=1$, $\ldots, N ; E_{r}$ - the total number of employees in region $r$.

We applied a panel fixed effect estimation for industry-level regional data based on a neoclassical growth theory. We estimated an equation with and without year fixed effects to consider time-specific shocks and their impact on estimated results. Estimated model (2) was as follows:

$$
G D P g r_{i t}=\beta_{1} \text { Spec }_{i t}+\beta_{2} G D P_{i t-1}+\beta_{3} \text { Employ }_{i t}+\beta_{4} G F C F_{i t}+\beta_{5} E D U_{i t}+\mu_{i}+\eta_{t}+\varepsilon_{i t}
$$

where GDPgr $r_{i t}$-an annual growth of GDP per inhabitant in region $i$ and period $t, r=1$, ... , M; Spec $_{i t}$-regional specialization (Specialization ${ }_{r}$ in Equation (3)); GDP $P_{i t-1}$-lagged GDP per inhabitant; Employ $y_{i t}$-an annual growth of employed persons; GFCF $F_{i t}$ gross fixed capital formation per inhabitant; $E D U_{i t}$ - a percentage of the population with tertiary education; $\mu_{i}$ - unobserved individual fixed effects; $\eta_{t}$-time effects; $\varepsilon_{i t}$-an error term. $G D P_{i t-1}$ is involved due to the dependence of regional economic growth on the level of economic development (Monfort 2008). In the EU context, European regions with lower GDP per capita obtained higher cohesion funds related to the level of development for catching up with economically developed regions.

We have chosen to analyze the regional level rather than the national level. Smart specialization strategies were developed in the EU at the regional level. Additionally, for relative specialization analysis, regional data is more suitable for comparing units that are more similar in size from a territorial perspective and density of resources. Regions in the European Union are divided into administrative units according to the Nomenclature of Territorial Units for Statistics (NUTS). The NUTS classification was applied into a formal Regulation of the European Parliament and the Council in 2003 (Eurostat 2015). The NUTS harmonizes the collection of regional data, ensures comparable regional statistics for analysis, and for the comparison of the socio-economic situation and policy measures.

NUTS2 is a regional level for the application of regional policies in the EU. However, industry-level data of NUTS2 was limited for the analysis. Therefore, we analyzed data of NUTS1 level of 2008-2016, assuming that economic specialization is reflected in more aggregated territorial units. A time period was selected due to the regional and industrial data availability.

\subsection{Selection of Economic Sectors for Analysis}

Local markets are limited in size. For a region to achieve a higher specialization rate in some economic activities, it has to have at least part of the demand from foreign markets. For this reason, tradable sectors are involved in the analysis of economic specialization. Tradable sectors are those whose output is traded internationally, and it could be both goods and services (Gervais and Jensen 2019; Francois and Hoekman 2010). 
A set of studies have focused on the manufacturing sector, implicitly assuming that services are non-tradable, but this traditional assumption that goods are tradable and services are non-tradable is increasingly inadequate. Gervais and Jensen (2019) stated that service trade has grown over time and now accounts for about $20 \%$ of global international transactions, and tradable service industries account for about the same share of value added as tradable manufacturing industries in the US. The potential welfare gains from trade liberalization in the service sector seem considerable (Francois and Hoekman 2010). In a globalized economy, services form a significant part of international trade. Therefore, service sectors have to be included in the analysis of economic specialization.

There is a discussion on how to separate tradable vs. non-tradable sectors. For example, Moretti and Thulin (2012) defined the non-tradable sector as locally produced and consumed services and the tradable sector as manufacturing and a part of the service sector that were exported outside the local economy. Kemeny and Storper (2014) calculated the Herfindahl index of geographical concentration to find a cut-off point in the distribution of concentration values at which tradable activities are distinguished from non-tradable in the US metropolitan areas, stating that if sectors are spatially ubiquitous, they had to be generally non-tradable (Jensen and Kletzer 2005). Herfindahl index of geographical concentration (Concj) is evaluated by the formula:

$$
\text { Conc }_{j}=\sum_{k=1}^{K}\left(\frac{e_{j k}}{E_{j}}\right)^{2}
$$

where $e$-employment in industry $j$ and city $k ; E$ is the total employment across all cities in industry $j$. Herfindahl index values vary from 0 to 1 , while industries with values near 0 exhibit a uniform distribution over space, while values closer to 1 indicate sectors with highly concentrated activity in only a few locations.

With no clear theoretical guidance on such a cut-off, Kemeny and Storper (2014) have chosen to eliminate sectors with a lower Herfindahl index rate (lower than 0.036) that seemed to differentiate non-tradable from tradable sectors in practice. For example, eliminated sectors were death care services, retail stores, car repairing, architectural services, etc. We used this approach to evaluate the distribution of economic activities between European regions with an expansion.

While analyzing the Herfindahl index of geographical concentration for sectors in the EU, some sectors with a comparatively low Herfindahl index have high specialization values (LQ, Equation (1)). For example, almost all regions in the EU had wholesale and retail trade and repair of motor vehicles and motorcycle activities (sector code-G45). The Herfindahl index was close to $0(0.0161)$ because such activities are in all regions. However, for example, in the LT0 region, the LQ index of this sector was high $(\mathrm{LQ}=1.42)$, revealing that a variety of companies in LT0 were repairing and re-exporting motor vehicles and motorcycles to foreign markets and it was a significant part of their value added. The same situation occurred with accommodation and food and beverage services activities (codes of sectors-I55 and I56). All regions in the EU had such activities that meant low HI (0.0187 and 0.0185). However, some regions focused on tourism, e.g., the Crete region, which was highly specialized in these sectors with high LQ values.

For this reason, we did not cut off all sectors with a comparatively small Herfindahl index in the way Kemeny and Storper (2014) did with the US data. This approach seemed not suitable for EU data because there were considerable differences in economic activities between EU regions and their economic structure. Therefore, we involved the LQ index in analysis for identifying the tradable sectors (Equation (1)). Rather than estimating the impact of specialization in the full range of all sectors, we focused on tradable sectors. We eliminated such sectors as veterinary activities, rental and leasing activities, employment activities, retail trade, water supply, etc. Moreover, we did not involve sectors such as C32-other manufacturing or M74-other professional, scientific, and technical activities because of the aggregated data of different types of economic activities under the same 
code. We involved 48 industries in the analysis according to NACE classification. NACE classification groups together economic activities that have similar input and production techniques and similar outputs. A final list of sectors involved in the analysis is presented in Appendix A.

\section{Results}

This part first represents an overview of the level of economic specialization in the EU regions during the period analyzed and then gives insights about estimation results of economic specialization impact on economic growth. A broader discussion of the results is presented in the following part.

All EU regions tended to have a weighted average specialization (Specialization $n_{r}$ ) above 1 (Figure 1) during the period analyzed. It revealed that all regions had some areas of specialization. The intensity of regional specialization varied from around 1.09 to 1.93, with most regions with a specialization rate not above 1.49. Usually, those regions were specialized in some specific sector which distinguished them from other regions, e.g., the NL1 (Noord-Nederland) region, which was mainly focused on water transport (H50), or the PL2 (Makroregion Poludniowy) region, which was specialized in mining and quarrying (B) activities.

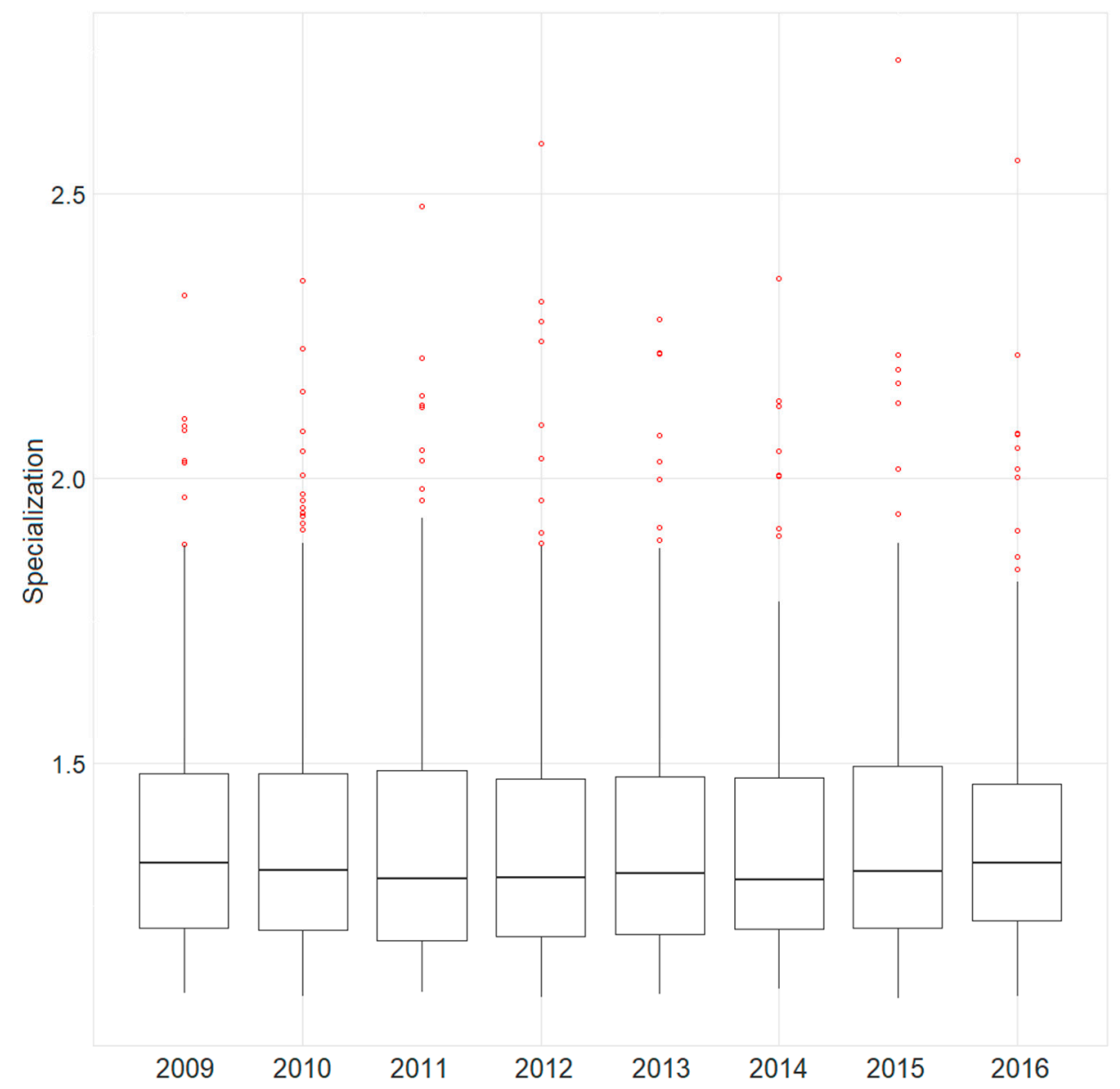

Figure 1. Median Specialization ${ }_{r}$ in NUTS1 regions of the EU in 2009-2016. Source: Eurostat, author's calculations.

A majority of European regions were comparatively not highly specialized and served a variety of different activities. This tendency was changing very gradually. The median specialization varied from 1.30 to 1.33 and had no clear tendency of change for the overall sample from 2009 to 2016 (Figure 1). No clear tendency reveals both specialization and diversification processes. The median specialization was at a comparatively similar level. 
There was a highly mixed picture of economic specialization changes while analyzing different regions in the European Union (Figure 2). Some regions became more specialized while others became more diversified, and a majority of the regions stayed more or less at the same level of economic specialization. For example, NL1 (Noord-Nederland), DE5 (Bremen), and EL6 (Kentriki Ellada) were among those regions where specialization increased. Meanwhile, DE8 (Mecklenburg-Vorpommern), PT1 (Continente), and LU0 (Luxembourg) were among those regions where specialization decreased. It was closely related to the economic activities that regions were serving. In some capital regions, a lower specialization was due to the growing diversity of economic activities within a territory.

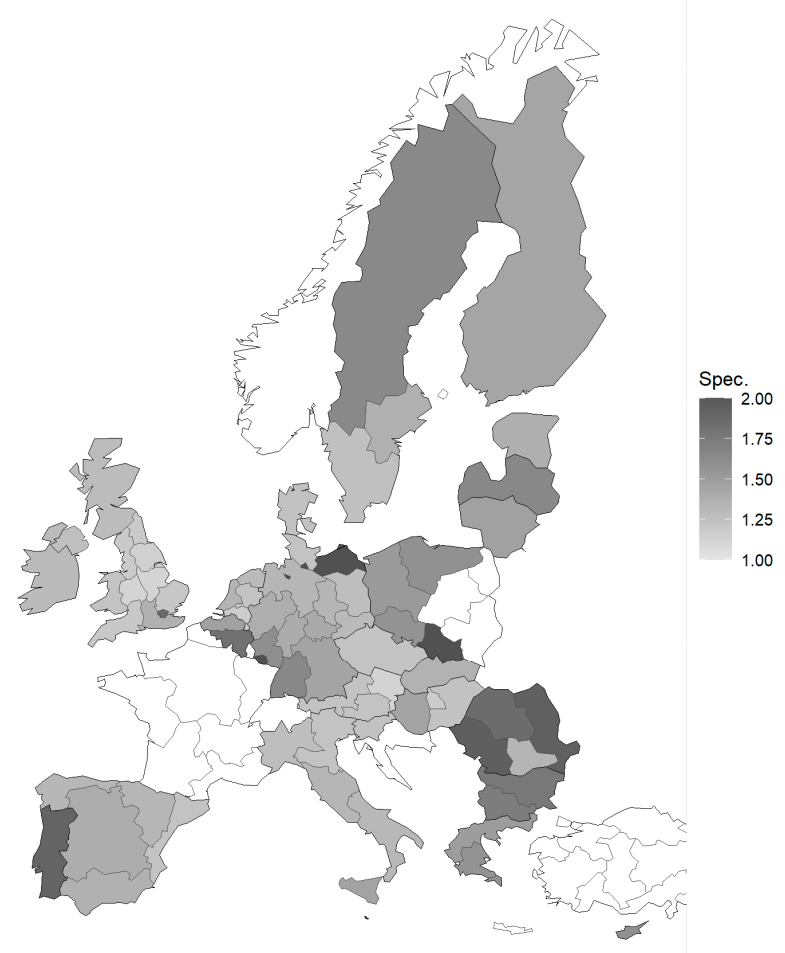

(a)

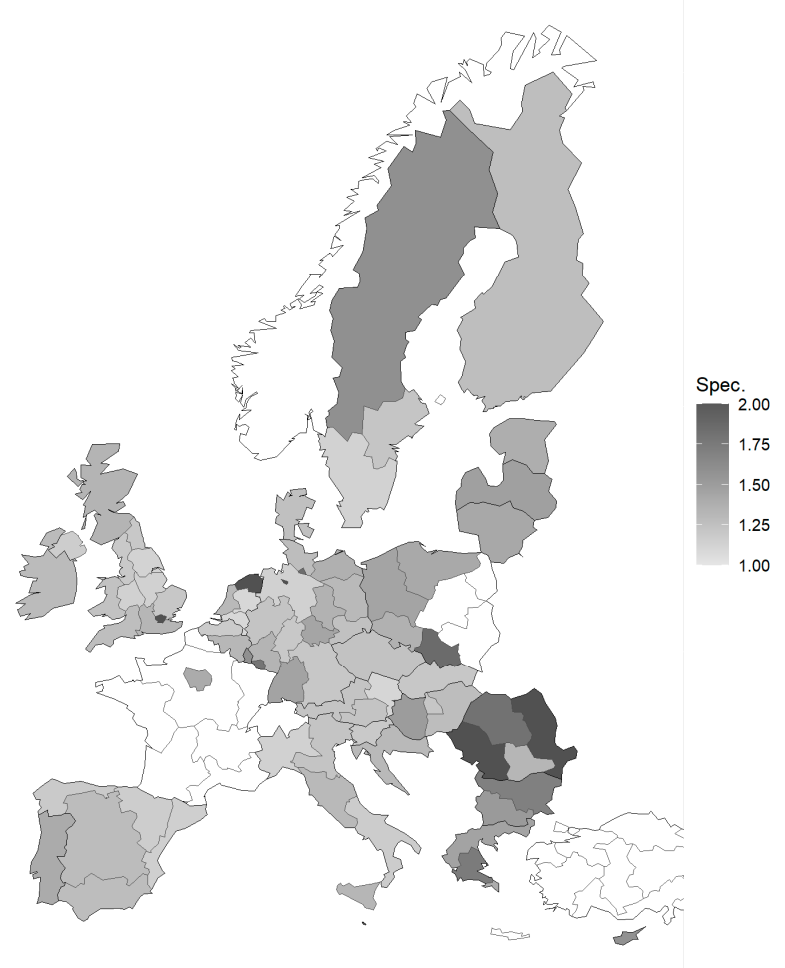

(b)

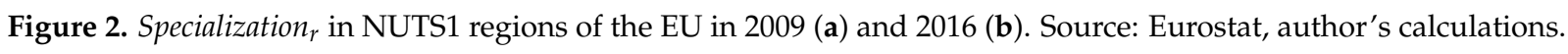

There was no clear relation of changes in the economic specialization to the regional economic growth. Some economically strong regions got more specialized and vice versa. However, more specialized regions hold a risk of technology change or losses in demand that could emerge in the long run. Significantly, at a higher risk are lagging regions with lower learning capabilities. Lu et al. (2011) for Chinese regions or Sotarauta and Suvinen (2019) for Norway regions revealed that higher specialization is supposed to be related to lower diversity and lower growth perspectives.

Further, we estimated the contribution of economic specialization to regional economic development by a panel fixed effect estimation (Table 1). All control variables, such as capital, employment, and education, statistically significantly contributed to regional economic growth. There was a strong link between the income level (GDP pc-1) and economic growth. Regions with lower GDP per capita had higher economic growth rates, and it reveals catching-up processes at the EU regional level. 
Table 1. Estimation results.

\begin{tabular}{lcc}
\hline & \multicolumn{2}{c}{ Dependent Variable: GDP Growth } \\
\cline { 2 - 3 } & Estimation 1 & Estimation 2 \\
\hline Specialization & 0.037 & 0.047 \\
& $(0.031)$ & $(1.199)$ \\
GDP pc-1 & $-0.416^{* * *}$ & $-0.337^{* * *}$ \\
Employment & $(0.078)$ & $(0.07)$ \\
& $0.768^{* * *}$ & $0.500^{* * *}$ \\
Gross fixed capital formation & $(0.127)$ & $(0.103)$ \\
& $0.163^{* * *}$ & $0.134^{* * *}$ \\
Education & $(0.024)$ & $(0.021)$ \\
& $0.006^{* * *}$ & -0.0005 \\
Individual effects & $(0.001)$ & $(0.001)$ \\
Time effects & Yes & Yes \\
Observations & No & Yes \\
$\mathrm{R}^{2}$ & 586 & 586 \\
Adjusted $\mathrm{R}^{2}$ & 0.318 & 0.185 \\
F statistic & 0.201 & 0.031 \\
& $46.603^{* * *}$ & $22.284^{* * *}$ \\
\hline
\end{tabular}

Note: ${ }^{* * *} p<0.01$; models are estimated with heteroskedasticity- and autocorrelation-consistent (HAC) standard errors.

The estimation results revealed an ambiguous impact of economic specialization on economic growth in the EU regions that complements the visual analysis presented in Figure 2. Higher specialization rates were associated with higher gross value added, indicated by positive coefficient signs. However, this effect was statistically insignificant in both estimations, so we cannot affirm economic specialization or diversification impact for economic growth in the EU.

We may argue that either economic specialization or diversification of the economic structure does not necessarily reveal its prospect to economic growth, and it is very case specific in the EU. Regions in the EU differ in many senses-catching-up economies or advanced economies, rural or urban areas, innovation leaders or modest innovators. Therefore, this research revealed that the impact of the economic specialization in the EU is not as straightforward as it was for the cases of one country's inner regions. For example, in China tendency was definite. Specialization increased in economically shrinking regions, and diversification processes took place in mostly urbanized and economically advanced areas ( $\mathrm{Lu}$ et al. 2011). These findings reveal the complexity of formation of regional innovation policy in the EU.

\section{Discussion}

From the scientific literature, the economic specialization or diversification processes are supposed to drive regional economic development, but it is not straightforward in the EU regions, and our finding supports that. Related research findings with an ambiguous relationship between economic specialization and regional economic development could be found in other research, i.e., Kemeny and Storper (2014), Russu (2015), and Kaulich (2012).

Different cases supplement our research finding by explaining a multiplicity of the impact of economic specialization on economic growth. If specialization emerges in more complex and knowledge-intensive areas, it most likely gives a promising path for further regional development (Hausmann et al. 2007; Iacobucci and Enrico 2016; Capello and Kroll 2016; Balland and Boschma 2021). If specialization happens in less urbanized territories with traditional manufacturing sectors, it commonly reveals a shrinking economy with diminishing concentration of economic resources and a lowering of the variety of economic activities (i.e., Lu et al. 2011; Russu 2015; Sotarauta and Suvinen 2019). Likewise, it is questionable whether a higher diversification in the region is due to new emerging industries 
or because of current specialization areas in decline. This idea of the different nature of economic specialization and diversification comprises a space for further research-capturing these dynamics in the economic structure and forming guidance for policy formation. The answer is not straightforward.

The relative specialization index of location quotient reveals a degree of economic specialization but does not reveal the nature of specialization or diversification. Increasing or decreasing specialization could be of positive or negative influence on regional economic development, and it is very case specific, especially for broadly diversified regions in the EU.

The case of Finland illustrates the complexity of economic specialization or diversification processes. From first sight, specialization in the ICT could be an essential path for regional development in the context of the fourth industrial revolution and the rise of the ICT sector (Dzemydiene et al. 2020). However, many jobs were lost in the ICT industry in Finland because of sharp technological change and global competition (Sotarauta and Suvinen 2019). Such cases reveal the fast-changing global environment and a need for regions to have a capacity to reinvent themselves and to adapt to the market changes (Balland et al. 2019). Specialization in some high-tech sectors does not necessarily guarantee a key for regional economic development in the end. We consider it essential for regional economic growth in the long run whether the region can learn and develop a continuous stream of competitive products for the global markets.

While coming to the question to what extent higher specialization rates, measured by location quotient, reveal prospective areas for economic growth and to what extent such analysis could be valuable in the policy formation of smart specialization strategies, the answer is considerably straightforward. Our research results supplement the findings of Kemeny and Storper (2014) in a sense of critically assessing a measure of relative specialization and its impact on economic development. These researchers found that the larger scale of the industry made a significant contribution to wages and productivity. However, the relative footprint of an industrial specialization in broader regional employment, measured by location quotient, was not significantly associated with wages. We may agree that economic specialization measures, particularly the location quotient, cannot capture dynamics in the industry structure that could be essential for economic development. This technique reveals changes in the economic structure but does not necessarily reveal prospective growth areas.

The paper has some limitations, however. Qualitative methods seem to be needed to fully understand the features of structural change in the regional economies (Grillitsch and Asheim 2018). Economic specialization measure by location quotient and other quantitative techniques (Foray et al. 2012; Balland et al. 2019) has considerable limitations. One of the limitations is that quantitative techniques cannot capture processes of social innovation that are of growing importance (Marques et al. 2018). The patent data that is also widely applied for a search of potential areas (Kogler et al. 2017; D'Adda et al. 2019; Balland et al. 2019; Balland and Boschma 2021) cannot thoroughly capture innovative processes in service sectors or areas where new knowledge is generally not patented (Witell et al. 2016; Izsak et al. 2020). How to capture these dynamics in the economic structure remains a question for further research.

One more limitation of this research is the availability of industrial data at the NUTS2 territorial level. We had unbalanced datasets with aggregated industrial data that were not suitable for more in-depth economic specialization analysis for such regions. The NUTS1 level was selected to solve this shortcoming. However, we may argue that some specific dynamics could be captured at a lower territorial breakdown, e.g., higher specialization rates could emerge because of the size of the economy. A lower territorial breakdown could be a case for further research. 


\section{Conclusions}

The main issue behind the policymaking for formation of smart specialization strategies is how to shift regional economic development towards smart growth and how to facilitate success of new prospective economic activities. Various EU regions applied the LQ index for specialization analysis as the first step in the formation of smart specialization strategy. Economic specialization concerns not only location quotients, but also regional concentration of competencies and knowledge. It is supposed to reveal regional industrial structures where higher value added and exports are generated.

This paper aimed to investigate the impact of economic specialization on regional economic development and to give insights into identification of prospective areas in regional economies. The main findings suggest that economic specialization is inconsistently associated with higher gross value added with positive but statistically insignificant effects. Both economic specialization or diversification processes took place in EU regions and had a different impact on economic growth. The relative specialization index of the location quotient identifies a degree of economic specialization. However, it does not reveal the broader context of specialization or diversification process that could reflect the potential of economic activities in a broader perspective. These findings confirm the complexity of regional innovation policy formation in the EU. There is a need for a mixture of different approaches, also a qualitative approach, for identification of prospective growth areas.

Based on our findings, neither economic specialization nor economic diversity are clear-cut solutions for ensuring economic growth. Economic structure in EU regions differs and there is no one answer to which approach is better for economic development. Economic specialization measures, particularly the location quotient, cannot capture the dynamics in industry structure that could be essential for identification of prospective growth areas. Formation of smart specialization strategy remains case specific. A placebased approach for policy formation is a solution because the 'one policy suits all' approach is not suitable for regional development in the EU.

Funding: This research received no external funding.

Institutional Review Board Statement: Not applicable.

Informed Consent Statement: Not applicable.

Data Availability Statement: Publicly available datasets were analyzed in this study. This data can be found here: [https:/ / ec.europa.eu/eurostat/data/database, code: sbs_r_nuts06_r2], (accessed on 20 February 2021).

Conflicts of Interest: The author declares no conflict of interest.

Appendix A

Table A1. Herfindahl index for geographic concentration of sectors (NACE) in EU NUTS 1 regions.

\begin{tabular}{llc}
\hline Code & Description & Herfindahl Index \\
\hline \multicolumn{2}{l}{ Sectors involved in the analysis (tradable sectors) } & 0.0541 \\
\hline B & Mining and quarrying & 0.0150 \\
C10 & Manufacture of food products & 0.0205 \\
C11 & Manufacture of beverages & 0.1359 \\
C12 & Manufacture of tobacco products & 0.0327 \\
C13 & Manufacture of textiles & 0.0391 \\
C14 & Manufacture of wearing apparel & 0.0657 \\
C15 & Manufacture of leather and related products & 0.0201 \\
C16 & Manufacture of wood and of products of wood and cork, except furniture; manufacture of & 0.0197 \\
C17 & articles of straw and plaiting materials & 0.0184 \\
C18 & Manufacture of paper and paper products & \\
\hline
\end{tabular}


Table A1. Cont.

\begin{tabular}{|c|c|c|}
\hline Code & Description & Herfindahl Index \\
\hline \multicolumn{3}{|c|}{ Sectors involved in the analysis (tradable sectors) } \\
\hline C19 & Manufacture of coke and refined petroleum products & 0.0534 \\
\hline $\mathrm{C} 20$ & Manufacture of chemicals and chemical products & 0.0315 \\
\hline $\mathrm{C} 21$ & Manufacture of basic pharmaceutical products and pharmaceutical preparations & 0.0275 \\
\hline $\mathrm{C} 22$ & Manufacture of rubber and plastic products & 0.0226 \\
\hline $\mathrm{C} 23$ & Manufacture of other non-metallic mineral products & 0.0201 \\
\hline $\mathrm{C} 24$ & Manufacture of basic metals & 0.0344 \\
\hline $\mathrm{C} 25$ & Manufacture of fabricated metal products, except machinery and equipment & 0.0227 \\
\hline $\mathrm{C} 26$ & Manufacture of computer, electronic, and optical products & 0.0304 \\
\hline $\mathrm{C} 27$ & Manufacture of electrical equipment & 0.0352 \\
\hline $\mathrm{C} 28$ & Manufacture of machinery and equipment N.E.C. & 0.0435 \\
\hline $\mathrm{C} 29$ & Manufacture of motor vehicles, trailers, and semi-trailers & 0.0398 \\
\hline C30 & Manufacture of other transport equipment & 0.0345 \\
\hline C31 & Manufacture of furniture & 0.0242 \\
\hline $\mathrm{D}$ & D Electricity, gas, steam, and air conditioning supply & 0.0329 \\
\hline F41 & Construction of buildings & 0.0178 \\
\hline F42 & Civil engineering & 0.0166 \\
\hline F43 & Specialized construction activities & 0.0165 \\
\hline G45 & Wholesale and retail trade and repair of motor vehicles and motorcycles & 0.0161 \\
\hline G46 & Wholesale trade, except of motor vehicles and motorcycles & 0.0177 \\
\hline $\mathrm{H} 49$ & Land transport and transport via pipelines & 0.0174 \\
\hline H50 & Water transport & 0.0580 \\
\hline H51 & Air transport & 0.0680 \\
\hline H52 & Warehousing and support activities for transportation & 0.0210 \\
\hline H53 & Postal and courier activities & 0.0334 \\
\hline I55 & Accommodation & 0.0187 \\
\hline I56 & Food and beverage service activities & 0.0185 \\
\hline $\mathrm{J} 58$ & Publishing activities & 0.0315 \\
\hline J59 & $\begin{array}{l}\text { Motion picture, video and television program production, sound recording, and music } \\
\text { publishing activities }\end{array}$ & 0.0418 \\
\hline $\mathrm{J} 60$ & Programming and broadcasting activities & 0.0450 \\
\hline J61 & Telecommunications & 0.0258 \\
\hline J62 & Computer programming, consultancy, and related activities & 0.0254 \\
\hline J63 & Information service activities & 0.0259 \\
\hline $\mathrm{L}$ & L Real estate activities & 0.0178 \\
\hline M69 & Legal and accounting activities & 0.0201 \\
\hline M70 & Activities of head office; management consultancy activities & 0.0283 \\
\hline M71 & Architectural and engineering activities; technical testing and analysis & 0.0185 \\
\hline M72 & Scientific research and development & 0.0259 \\
\hline M73 & Advertising and market research & 0.0272 \\
\hline \multicolumn{3}{|c|}{ Sectors excluded from the analysis (non-tradable sectors and other sectors) } \\
\hline M75 & Veterinary activities & 0.0173 \\
\hline N77 & Rental and leasing activities & 0.0188 \\
\hline N78 & Employment activities & 0.0252 \\
\hline N79 & Travel agency, tour operator, reservation service, and related activities & 0.0211 \\
\hline N80 & Security and investigation activities & 0.0210 \\
\hline N81 & Services to building and landscape activities & 0.0233 \\
\hline N82 & Office administrative, office support, and other business support activities & 0.0258 \\
\hline G47 & Retail trade, except motor vehicles and motorcycles & 0.0166 \\
\hline E & Water supply; sewerage, waste management and remediation activities & 0.0184 \\
\hline $\mathrm{C} 32$ & Other manufacturing & 0.0232 \\
\hline $\mathrm{C} 33$ & Repair and installation of machinery and equipment & 0.0171 \\
\hline M74 & Other professional, scientific, and technical activities & 0.0230 \\
\hline
\end{tabular}




\section{References}

Akcigit, Ufuk. 2017. Economic growth: The past, the present, and the future. Journal of Political Economy 125: 1736-47. [CrossRef]

Arrow, Kenneth. 1962. Economic welfare and the allocation of resources for invention. In The Rate and Direction of Inventive Activity: Economic and Social Factors. Princeton: Princeton University Press, pp. 609-26. Available online: http://www.nber.org/chapters/ c2144.pdf (accessed on 20 February 2021).

Balland, Pierre-Alexandre, and Ron Boschma. 2021. Mapping the potentials of regions in Europe to contribute to new knowledge production in Industry 4.0 technologies. Regional Studies 1-15. [CrossRef]

Balland, Pierre-Alexandre, Ron Boschma, Joan Crespo, and David Rigby. 2019. Smart specialization policy in the European Union: Relatedness, knowledge, complexity, and regional diversification. Regional Studies 53: 1252-68. [CrossRef]

Barca, Fabrizio, Philip McCann, and Andrés Rodríguez-Pose. 2012. The case for regional development intervention: Place-based versus place-neutral approaches. Journal of Regional Science 52: 134-52. [CrossRef]

Barroeta, Belen, Javier Gómez Prieto, Jonatan Paton, Manuel Palazuelos, and Marcelino Cabrera Giraldez. 2017. Innovation and regional specialisation in Latin America. EUR 28511 EN. [CrossRef]

Benner, Maximilian. 2020. Six additional questions about smart specialization: Implications for regional innovation policy 4.0. European Planning Studies 28: 1667-84. [CrossRef]

Boschma, Ron, and Ron Martin. 2010. The Handbook of Evolutionary Economic Geography. Cheltenham: Edward Elgar.

Capello, Roberta, and Henning Kroll. 2016. From theory to practice in smart specialization strategy: Emerging limits and possible future trajectories. European Planning Studies 24: 1393-406. [CrossRef]

Capello, Roberta. 2016. Regional Economics, 2nd ed. New York: Routledge.

Content, Jeroen, Koen Frenken, and Jacob Jordaan. 2019. Does related variety foster regional entrepreneurship? Evidence from European regions. Regional Studies 53: 1531-43. [CrossRef]

D'Adda, Diego, Enrico Guzzini, Donato Iacobucci, and Roberto Palloni. 2019. Is smart specialisation strategy coherent with regional innovative capabilities? Regional Studies 53: 1004-16. [CrossRef]

De Groot, Henri, Jacques Poot, and Martijn Smit. 2009. Agglomeration Externalities, Innovation and Regional Growth: Theoretical Perspectives and Meta-analysis. In Handbook of Regional Growth and Development Theories. Cheltenham: Edward Elgar Publishing Ltd., pp. 256-81.

Dietz, Richard, and Ramon Garcia. 2002. Economic Diversity and New York State. The Regional Economy of Upstate New York. New York: Federal Reserve Bank of New York.

Dosso, Mafini, Alexander Kleibrink, and Monika Matusiak. 2020. Smart specialisation strategies in sub-Saharan Africa: Opportunities, challenges and initial mapping for Côte d'Ivoire. African Journal of Science, Technology, Innovation and Development. [CrossRef]

Duranton, Gilles, and Anthony James Venables. 2018. Place-based policies for development. In Policy Research Working Paper, WPS 8410. Washington, DC: World Bank Group.

Duranton, Gilles, and Diego Puga. 2004. Micro-foundations of urban agglomeration economies. In Handbook of Regional and Urban Economics. Edited by John Vernon Henderson and Jacques-François Thisse. Amsterdam: Elsevier, pp. 2063-117.

Dzemydienè, Dalè, Giedrè Dzemydaitè, and Dinesh Gopisetti. 2020. Application of multicriteria decision aid for evaluation of ICT usage in business. Central European Journal of Operations Research 1-21. [CrossRef]

European Commission. 2015. Territorial Agenda 2020 Is Put in Practice. Enhancing the Efficiency and Effectiveness of Cohesion Policy by a Place-Based Approach. Milan: CSIL, Centre for Industrial Studies.

European Commission. 2017a. Challenges Ahead: Boosting Innovation-Led Growth in EU Regions. Memo-17-1995. Brussels: European Commission, July 18.

European Commission. 2017b. Communications from the Commission to the European Parliament, the Council, the European Economic and Social Committee and the Committee of the Regions. Strengthening Innovation in Europe's Regions: Strategies for Resilient, Inclusive and Sustainable Growth. COM(2017) 376 final. Brussels: European Commission, July 18.

Eurostat. 2015. Regions in the European Union. Nomenclature of Territorial Units for Statistics NUTS2013/EU-28.. Luxembourg: Publications Office of the European Union.

Foray, Dominique, Paul David, and Bronwyn Hall. 2009. Smart Specialisation-The Concept. Knowledge Economists Policy Brief No. 9. Available online: https://ec.europa.eu/invest-in-research/pdf/download_en/kfg_policy_brief_no9.pdf (accessed on 20 February 2021).

Foray, Dominique, Paul David, and Bronwyn Hall. 2011. Smart specialisation. From academic ideas to political instruments. The surprising career of a concept and the difficulties involved in its implementation. In MTEI-Working Paper. Lausanne: Ecole Polytechnique Fédérale de Lausanne.

Foray, Dominique, John Goddard, Xabier Goenaga Beldarrain, Mikel Landabaso, Philip McCann, Kevin Morgan, Claire Nauwelaers, and Raquel Ortega-Argilés. 2012. Guide to Research and Innovation Strategies for Smart Specialisation (RIS 3). European Commission, May, 2012. Available online: https://s3platform.jrc.ec.europa.eu/en/web/guest/w/guide-on-research-andinnovation-strategies-for-smart-specialisation-ris3-guide- (accessed on 20 February 2021).

Foray, Dominique. 2015. Smart Specialisation. Opportunities and Challenges for Regional Innovation Policy. London: Routledge.

Foray, Dominique. 2019. In response to 'Six critical questions about smart spezialisation'. European Planning Studies 27: $2066-78$. [CrossRef]

Francois, Joseph, and Bernard Hoekman. 2010. Services Trade and Policy. Journal of Economic Literature 48: 642-92. [CrossRef] 
Friesenbichler, Klaus Sylvester, and Christian Glocker. 2019. Tradability and productivity growth differentials across EU Member States. Structural Change and Economic Dynamics 50: 1-13. [CrossRef]

Gervais, Antoine, and Bradford Jensen. 2019. The tradability of services: Geographic concentration and trade costs. Journal of International Economics 118: 331-50. [CrossRef]

Gianelle, Carlo, Fabrizio Guzzo, and Krzysztof Mieszkowski. 2019. Smart specialisation: What gets lost in translation from concept to practice? Regional Studies 54: 1377-88. [CrossRef]

Glaeser, Edward Ludwig, Hedi Kallal, José Scheinkman, and Andrei Shleifer. 1992. Growth in cities. Journal of Political Economy 100: 1126-52. [CrossRef]

Grillitsch, Marcus, and Bjorn Asheim. 2018. Place-based innovation policy for industrial diversification in regions. European Planning Studies 26: 1638-62. [CrossRef]

Hassink, Robert, and Huiwen Gong. 2019. Six critical questions about smart specialization. European Planning Studies 27: $2049-65$. [CrossRef]

Hausmann, Ricardo, Jason Hwang, and Dani Rodrik. 2007. What You Export Matters. Journal of Economic Growth 12: 1-25. [CrossRef]

Henderson, John Vernon. 2003. Marshall's scale economies. Journal of Urban Economics 53: 1-28. [CrossRef]

Iacobucci, Donato, and Guzzini Enrico. 2016. Relatedness and connectivity in technological domains: Missing links in S3 design and implementation. European Planning Studies 24: 1511-26. [CrossRef]

Izsak, Kincsö, Paresa Markianidou, Els van de Velde, Rainer Frietsch, Henning Kroll, Sven Wydra, Mike Glennon, and Juan Mateos Garcia. 2020. Advanced Technologies for Industry—Methodological Report. Brussel: European Commission, European Union.

Jacobs, Jane. 1969. The Economy of Cities. New York: Vintage.

Jensen, J. Bradford, and Lori G. Kletzer. 2005. Tradable Services: Understanding the Scope and Impact of Services Outsourcing. Institute for International Economics Working Paper No. 05-9. Washington, DC: Institute for International Economics. [CrossRef]

Karo, Erkki, Rainer Kattel, and Aleksandr Cepilovs. 2017. Can smart specialization and entrepreneurial discovery be organized by the government? Lessons from Central and Eastern Europe. In Advances in the Theory and Practice of Smart Specialization. Edited by Slavo Radosevic, Adrian Curaj, Radu Gheorgiu, Liviu Andreescu and Imogen Wage. Amsterdam: Elsevier, pp. $270-93$.

Kaulich, Florian. 2012. Diversification vs. Specialization as Alternative Strategies for Economic Development: Can We Settle a Debate by Looking at the Empirical Evidence? Vienna: United Nations Industrial Development Organization (UNIDO).

Kemeny, Thomas, and Michael Storper. 2014. Is Specialization Good for Regional Economic Development? Regional Studies 49: 1003-18. [CrossRef]

Kleibrink, Alexander, Philippe Larédo, and Stefan Philipp. 2017. Promoting Innovation in Transition Countries: A Trajectory for Smart Specialization. EUR 28638 EN. Brussel: European Union. [CrossRef]

Kogler, Dieter Franz, Jürgen Essletzbichler, and David Rigby. 2017. The evolution of specialization in the EU15 knowledge space. Journal of Economic Geography 17: 345-73. [CrossRef]

Liu, Hao. 2019. The communication and European Regional economic growth: The interactive fixed effects approach. Economic Modelling 83: 299-311. [CrossRef]

Lu, Zheng, Tony Flegg, and Deng Xiang. 2011. Regional specialization: A measure method and trends in China. MPRA Paper 33867. pp. 1-14. Available online: https://mpra.ub.uni-muenchen.de/33867/1/MPRA_paper_33867.pdf (accessed on 20 February 2021).

Mameli, Francesca, Simona Iammarino, and Ron Boschma. 2012. Regional variety and employment growth in Italian labour market areas: Services versus manufacturing industries. Papers in Evolutionary Economic Geography 12: 1-23.

Marques, Pedro, Kevin Morgan, and Renald Richardson. 2018. Social innovation in question: The theoretical and practical implications of a contested concept. Environment and Planning C: Politics and Space 36: 496-512. [CrossRef]

Marshall, Alfred. 1920. Principles of Economics: An Introductory Volume. London: Macmillan.

McCann, Phillip, and Raquel Ortega-Argilés. 2013. Transforming European regional policy: A results-driven agenda and smart specialization. Oxford Review of Economic Policy 29: 405-31. [CrossRef]

McCann, Phillip, and Raquel Ortega-Argilés. 2015. Smart specialization, regional growth and applications to European Union cohesion policy. Regional Studies 49: 1291-302. [CrossRef]

Misiak, Tomasz, and Paweł Dykas. 2021. Related and unrelated variety vs. basic labour market variables-Regional analysis for Poland. European Planning Studies 29: 221-40. [CrossRef]

Monfort, Philippe. 2008. Convergence of EU Region Measures and Evolution. A Series of Short Papers on Regional Research and Indicators Produced by the Directorate-General for Regional Policy, No 01/2008. Brussels: European Commission, Regional Policy.

Moretti, Enrico, and Per Thulin. 2012. Local multipliers and human capital in the United States and Sweden. Industrial and Corporate Change 22: 339-62. [CrossRef]

Paliokaite, Agnè, Žilvinas Martinaitis, and Ramojus Reimeris. 2015. Foresight methods for smart specialisation strategy development in Lithuania. Technological Forecasting and Social Change 101: 185-99. [CrossRef]

Postoiu, Constantin, and Anca Dachin. 2014. The Employment Profile and Its Relevance for the Regional Smart Specialization Strategy in Romania. Paper presented at 9th International Conference on Business Excellence, Bucharest, Romania, October 10; Available online: http:/ /www.managementmarketing.ro/ \{\}store/suplimente/Volum_ICBE_2015_BT.pdf (accessed on 20 February 2021).

Romer, Paul. 1990. Endogenous technological change. Journal of Political Economy 98: 71-102. [CrossRef] 
Russu, Corneliu. 2015. Industrial Specialization of the European Union Member Countries. Economic Insights-Trends and Challenges 67: 63-65.

Šidlauskaitè-Riazanova, Brigita, and Algirdas Miškinis. 2019. Aspects of the Development of Lithuanian Economic Specialisation in the Context of Globalization. Social Research 42: 59-73. [CrossRef]

Šidlauskaitè-Riazanova, Brigita. 2020. Assessment of the demand side pandemic impact on the EU economy in the context of globalization. Applied Economics: Systematic Research 14: 59-76. [CrossRef]

Skare, Marinko, Domingo Riberio Soriano, and Małgorzata Porada-Rochoń. 2021. Impact of COVID-19 on the travel and tourism industry. Technological Forecasting and Social Change 163. [CrossRef]

Solow, Robert Merton. 1952. On the Structure of Linear Models. Econometrica 20: 29-46. [CrossRef]

Sotarauta, Markku, and Nina Suvinen. 2019. Place leadership and the challenge of transformation: Policy platforms and innovation ecosystems in promotion of green growth. European Planning Studies 27: 1748-67. [CrossRef]

Trippl, Michaela, Elena Žukauskaite, and Adrian Healy. 2020. Shaping smart specialisation: The role of place-specific factors in advanced, intermediate and less-developed European regions. Regional Studies 54: 1328-40. [CrossRef]

Van Oort, Frank, Stefan de Geus, and Teodora Dogaru. 2015. Related variety and regional economic growth in a cross-section of European urban regions. European Planning Studies 23: 1110-27. [CrossRef]

Witell, Lars, Hannah Snyder, Anders Gustafsson, Paul Fombelle, and Per Kristensson. 2016. Defining service innovation: A review and synthesis. Journal of Business Research 69: 2863-72. [CrossRef]

Zhang, Hanyuan, Haiyan Song, Long Wen, and Chang Liu. 2021. Forecasting tourism recovery amid COVID-19. Annals of Tourism Research 87: 103-49. [CrossRef] 